\title{
Performance of purslane biomass production (Portulaca oleracea) under different organic substrate concentrations
}

\section{Desempenho na produção de biomassa de beldroega (Portulaca oleracea) sob diferentes concentrações de substrato orgânico}

\section{J. Elias de Oliveira ${ }^{1,2}$, J. Barboza Pereira ${ }^{1}$, Ch. G. da Silva ${ }^{1}$, A. das Graças Teixeira ${ }^{1}$, L. Pin Dalvi ${ }^{1}$, F. L. de Oliveira ${ }^{1}$}

\begin{abstract}
Objectives: To evaluate different concentrations based on cattle manure as an alternative in purslane production. Methodology: The experiment was conducted in a greenhouse at the Center for Agricultural Sciences and Engineering of the Federal University of Espirito Santo in Alegre, ES/ Brazil. The experimental arrangement used was a completely randomized design (CRD) with 5 treatments and 6 replications. The treatments consisted of distinct dosages of the substrate based on cattle manure $(0 \mathrm{~mL} ; 125 \mathrm{~mL} ; 250 \mathrm{~mL} ; 500 \mathrm{~mL}$ and $1000 \mathrm{~mL})$, which were applied in $5 \mathrm{~L}$ of soil, considered as an experimental unit. Root dry mass and aerial dry mass were evaluated. Results: Application of $500 \mathrm{~mL}$ of cattle manure provided a higher accumulation of shoot dry mass $(25 \mathrm{~g} / \mathrm{plant})$. For root dry mass, there were no statistically significant differences. Conclusions: Under the conditions of the present work, it is concluded that the use of organic manure with cattle manure is viable.
\end{abstract}

Keywords: Organic fertilization, fertilization levels, cattle manure; dry weight.

\section{Resumo}

Objetivos: Avaliar diferentes concentrações a base de esterco bovino como alternativa na produção de beldroega. Metodologia: O experimento foi conduzido em casa de vegetação do Centro de Ciências Agrárias e Engenharias da Universidade Federal do Espírito Santo em Alegre, ES/Brasil. O arranjo experimental utilizado foi o delineamento inteiramente casualizado (DIC), com 5 tratamentos e 6 repetições. Os tratamentos foram constituídos pelas dosagens distintas de substrato a base de esterco bovino $(0 \mathrm{~mL} ; 125 \mathrm{~mL} ; 250 \mathrm{~mL} ; 500 \mathrm{~mL}$ e $1000 \mathrm{~mL})$, as que foram aplicadas em $5 \mathrm{~L}$ de solo, considerada como uma unidade experimental. Avaliaram-se massa seca radicular e massa seca aérea. Resultados: O cultivo com $500 \mathrm{~mL}$ de esterco bovino proporcionou maior acúmulo de massa seca da parte aérea ( $25 \mathrm{~g} /$ planta). Para a massa seca da raiz, não houve diferença estatística constatada. Conclusões: Nas condições do presente trabalho conclui-se que é viável a utilização de adubação orgânica com esterco bovino.

Palavras-chave: Adubação Orgânica, Níveis de Adubação, Esterco Bovino, Produção de Massa Seca.

\section{Introduction}

The purslane (Portulaca oleracea) is a plant belonging to the Portulacaceae family, well known for its rapid growth and tolerance to water deficit, having potential for food and medicinal use in the treatment of some diseases such as cardiovascular, diabetes, cancer, hypertension and others (Acedo et al., 2012). In addition, it is an excellent source of omega-3, containing more fatty acids than some fish oils, as well as high nutritional value and antioxidants (Uddin et al.,

\footnotetext{
${ }^{1}$ Universidade Federal do Espírito Santo, Espírito Santo-ES, Brasil.

${ }^{2}$ Corresponding author: juliana.elias.o@hotmail.com
} 
2014). Weeds, either invasive or spontaneous, as they are popularly known in different regions, are those that interfere with the objectives of man in a given situation in an agroecosystem. It may be an indicator of the chemical and physical conditions of the soil (Gomes, 2008). Some species are indicative of soil fertility, such as $P$. oleracea which is indicative of fertile soils and a great ally of farmers in decision-making to adopt the most appropriate soil management (Gervazio et al., 2014).

The success of any crop depends, among other factors, on fertile soils, ensuring a good setting, resulting in reduced replanting costs, and promoting rapid initial plant growth. The solid residues generated by cattle stand out for presenting high concentrations of NPK and rapid mineralization, allowing greater availability of these nutrients to the plant. Thus, it has the potential to be used as a fertilizer, mainly by family farming (Silva et al., 2012).

With the purpose of developing knowledge about viable alternatives in the use of organic substrates, this work aimed to evaluate different concentrations based on cattle manure as an alternative in purslane production.

\section{Methodology}

The experiment was conducted in a greenhouse at Centro de Ciências Agrárias e Engenharias da Universidade Federal do Espírito Santo em Alegre - ES/Brazil, located at an altitude of $119 \mathrm{~m}$, with geographic coordinates $20^{\circ} 45^{\prime} 2.3^{\prime \prime}$ south latitude and $41^{\circ} 29^{\prime} 17.7^{\prime \prime}$ west longitude (Nogueira et al., 2012).

The experimental arrangement used was a completely randomized design (CRD) with 5 treatments and 6 replications, totaling 30 experimental units. The treatments were the different dosages of bovine manure substrate $(0$ $\mathrm{mL} ; 125 \mathrm{~mL} ; 250 \mathrm{~mL} ; 500 \mathrm{~mL}$ and $1000 \mathrm{~mL}$ ), which were applied to $5 \mathrm{~L}$ volumes of soil from each experimental unit.

The purslane propagation occurred asexually, by cutting, planting small stem cuttings in 5-liter pots, which were arranged in a greenhouse, with cover in translucent material with somber mesh, and allocated on a platform located approximately $90 \mathrm{~cm}$ from the ground.

Substrate preparation was performed with the process of tanning the manure, with the purpose of eliminating seeds of spontaneous plants, pathogens, parasites, besides increasing the $\mathrm{C} / \mathrm{N}$ ratio, in order to make it more balanced to the plants.

The evaluations took place at the end of the crop cycle in which the evaluated variables were: root dry matter (RDM) and shoot dry matter (SDM), with the removal of plants and subsequent cleaning by washing the roots and after this procedure, the root system and shoot were dried in a forced circulation oven at $60{ }^{\circ} \mathrm{C}$ for 48 hours. The statistical results obtained were subjected to analysis of variance by the " $F$ " test and the means to Tukey test at 5\% probability. All statistical analyzes were carried out with the aid of the R statistical software (R Core Team, 2018).

\section{Results and discussion}

According to the data obtained, it was verified that purslane when cultivated as a function of different concentrations of tanned manure, presented similar significant results in all treatments tested for the variable dry mass of the root. For the dry mass of the shoot, the treatment with $500 \mathrm{~mL}$ of cattle manure presented results significantly superior to the others, being significantly different statistically (Table 1).

According to Corrêa et al. (2003) the tendency of reduction of dry biomass from the maximum point of the organic fertilizer curve may be due to the excess of nutrients supplied to purslane, possibly affecting the root system and reducing nutrient absorption. This may explain why in the highest concentration of manure the response was similar to the treatment that received no dose of organic fertilizer. Note that the nutrient dosage must be balanced to obtain an optimal production, and deficiencies or excess nutrients cause disorders in plant growth.

Higher shoot dry mass values may possibly be explained by higher nutrient availability due to increased dosages, however, according 
Oliveira et al.

Table 1

Purslane root and shoot dry mass in response to different concentrations of cattle manure

\begin{tabular}{lcc}
\hline \multicolumn{1}{c}{$\begin{array}{c}\text { Doses of cattle manure } \\
\text { (mL/5 L soil })\end{array}$} & Root dry matter & Foliage dry matter \\
\cline { 2 - 3 } & & $(\mathrm{g} / \mathrm{plant})$ \\
\hline $0 \mathrm{~mL}($ Control $)$ & $4.00^{\mathrm{a}}$ & $15.83^{\mathrm{b}}$ \\
$125 \mathrm{~mL}$ & $4.00^{\mathrm{a}}$ & $15.67^{\mathrm{b}}$ \\
$250 \mathrm{~mL}$ & $3.83^{\mathrm{a}}$ & $18.17^{\mathrm{b}}$ \\
$500 \mathrm{~mL}$ & $4.00^{\mathrm{a}}$ & $25.00^{\mathrm{b}}$ \\
$1000 \mathrm{~mL}$ & $4.00^{\mathrm{a}}$ & $17.83^{\mathrm{b}}$ \\
\hline $\mathrm{CV}(\%)$ & 4.60 & 7.56 \\
\hline
\end{tabular}

a,b Means followed by the same letter in the column, do not differ from each other $(P>0.05)$.

to Furtini-Neto \& Tokura (2000) the excess of one nutrient in the soil reduces the efficacy of others and therefore it may decrease the yield of the crop if it occurred with the production of the dry mass of purslane shoots. In this sense, it is important to know the proper nutrient levels for fertilization in each species in order to reduce fertilization costs, maximize harvesting, and avoid phytotoxic effects.

\section{Conclusion}

Under the conditions of the present research, it is concluded that the use of organic manure with cattle manure is viable. Application of $500 \mathrm{~mL}$ of cattle manure provided greater accumulation of shoot dry mass $(25 \mathrm{~g} /$ plant $)$. For root dry mass, there was no statistically significant difference. However, research with the use of manure is of paramount importance to establish parameters for cultivation, dosages, and processing and utilization technologies that best suit the agricultural needs of this plant.

\section{References}

Acedo, J.Z., Reyes, C.T. \& Rodriguez, E.B. (2012). Health-Promoting Lipids From Purslane (Portulaca oleracea L.): Isolation, Characterization, Quantification, and In Vivo Assay of Angiogenic Activity. The Philippine Agricultural Scientist, 95 (4), 362-369.

Chaves, F.C. (2004). Produção de biomassa, rendimento e composição de óleo essencial de alfavaca-cravo (Ocimum gratissimum L.) em função da adubação orgânica e épocas de corte (tese doutorado). Universidade Estadual Paulista, São Paulo, Brasil.

Corrêa, R. M., Pinto, J. E. B. P., Reis, E. S., Costa, L. C. B., Alves, P. B., Niculan, E. S., \& Brant, R. S. (2010). Adubação orgânica na produção de biomassa de plantas, teor e qualidade de óleo essencial de orégano (Origanum vulgare L.) em cultivo protegido. Revista Brasileira de Plantas Medicinais, 12 (1), 80-89. doi.org/10.1590/ S1516-05722010000100012

Furtini-Neto, A.E., \& Tokura, A.M. (2000). Fertilidade e adubação de plantas medicinais. Lavras, Brasil: Universidade Federal de Lavras.

Gervazio, W., Rodrigues, C., Bessa, G. J. L., Silveira, G. S., \& Yamashita, O. M. (2014). Indicadores da qualidade do solo de um agroecossistema ecológico amazônico na visão etnopedológica. Enciclopédia biosfera, Centro Cientifico Conhecer Goiânia, 10 (19), 2312-2326.

Gomes JR, F. G., Christoffoleti, P. J. (2008). Biologia e manejo de plantas daninhas em áreas de plantio direto. Planta daninha, 26 (4), 789-798. doi.org/10.1590/S010083582008000400010

Nogueira, N. O., Tomaz, M. A., Andrade, F. V., Réis, E. F., \& Brinate, S. V.(2012). Influência da aplicação de dois resíduos industriais nas propriedades químicas de dois solos 
cultivados com café arábica. Revista Ciência Agronômica, 43 (1), 11-21. doi. org/10.1590/S1806-66902012000100002

Silva, J.A., Oliveira,A.P.,Alves, G.S., Cavalcante, L.F., Oliveira, A.N.P., \& Araújo, A.M. (2012). Rendimento do inhame adubado com esterco bovino e biofertilizante no solo e na folha. Revista Brasileira de Engenharia Agricola e Ambiental, 16 (3), 253-257. doi. org/10.1590/S1415-43662012000300003

R-Core Team. (2018). R: A Language and Environment for Statistical Computing. $\mathrm{R}$ Foundation for statistical computing. Vienna, Austria. Disponible en: https:// www.R-project.org/
Uddin, K., Juraimi, A.S, Hossain, S., Un Nahar, M.A. Ali, E. \& Rahman, M.M. (2014). Purslane Weed (Portulaca oleracea): A prospective plant source of nutrition Omega-3 fatty acid, and antioxidant attributes. The Scientific World Journal, 2014,1-6. doi.org/10.1155/2014/951019 